\title{
Research on Curriculum Design of Higher Vocational Education Based-on QFD
}

\author{
${ }^{\mathrm{a}}$ Sun Xuemei, ${ }^{\mathrm{b}}$ Xue Shiju \\ ${ }^{a}$ School of Computer Science and Software Engineering Tianjin Polytechnic University Tianjin, China \\ ${ }^{b}$ Civil Aviation University of China Tianjin, China
}

\begin{abstract}
The currently irrational curriculum design of advanced vocational education leads to the problem between personnel training and market requirements in our country. Aiming at this, the paper establishes "House of Quality" for the curriculum design by introducing the technique of Quality Function Deployment (QFD), and hereby proposes a new method of curriculum design of higher vocational education.
\end{abstract}

Index Terms: Vocational education; QFD; curriculum design

(C) 2012 Published by MECS Publisher. Selection and/or peer review under responsibility of the International Conference on E-Business System and Education Technology

\section{1. "STATEMENT OF THE PROBLEM"}

The training objective of advanced vocational education in our country is to bring up highly skilled applied talents, who should be geared to the needs of manufacturing, management, construction and service. However, the prominent problem in our country's vocational education is that the talents trained can't satisfy the needs of the society. The immediate cause of imbalance between supply and demand is that our higher vocational education takes the educational circles as the leading factor on the curriculum setting and curriculum development, that is to say the designers and developers are more adept at understanding the trend of technological development from the disciplinary perspective instead of grasping the mainstream technologies from the professional point of view, which makes the curriculum hard to get rid of the pattern of discipline systematization and to reflect the advanced and mainstreamed technologies, and much difficult to organize and design the vocational education curriculum. Therefore, the curriculum reform has become the central task of higher vocational education faced in our country. The main mission of curriculum development of higher vocational education is to answer these questions: (1) what are the requirements towards the talents for the social economy and labor market? (2) which type and structure of course could be adopted to achieve the goals more easily? (3) How to manage the curriculum? What qualities have here to guarantee the measures [1]?

Quality Function Deployment (QFD) is an effective tool to solve the issue above. Based on the idea of concurrent engineering, QFD is a kind of systematic management technology and the system design method of product, which drives for the customers' needs and accurately transforms the customer demands into product

* Corresponding author.

E-mail address: hhq_happy@126.com 
features via "House of Quality" so that meets the customer's demands by the greatest extent. By introducing QFD technology into the development and application of the higher vocational education, the paper constitutes the advanced vocational education curriculum design "House of Quality" and proposes a new approach of advanced vocational education curriculum design.

\section{Introduction of Quality Function Deployment}

Quality Function Deployment (QFD) was proposed by the Japanese quality expert Yoji Akao in 1972. It is applied in the Mitsubishi Heavy Industries Kobe Ship-building company in Japanese at the earliest and then introduced to America by Ford Company in 1984[2]. "House of Quality" is the basic tool of QFD and its basic form is shown in Fig.1: (1)the left wall---- WHATS input matrix, which is the "what" of the house of quality, is the description of customer demand and weight; (2)ceiling----HOWS matrix, which is the "how" of the house of quality, is the description of product engineering technology feature; (3)room----relevant relationship matrix, which is the relationship matrix of them, describes the interrelationship between the customer needs and engineering technology features; (4)the right wall----evaluating matrix, which evaluates the competitiveness of the products in the market from customers' perspective, is the competitive appraisal of product; (5)roof---HOWS interrelationship matrix, which indicates the interrelationship of all technology requirements; (6)Cellar--- HOWS output matrix, is the technical competitive assessment, technology importance and the target value, which is to ascertain the optimization deployed program and maintain the quality characteristic.

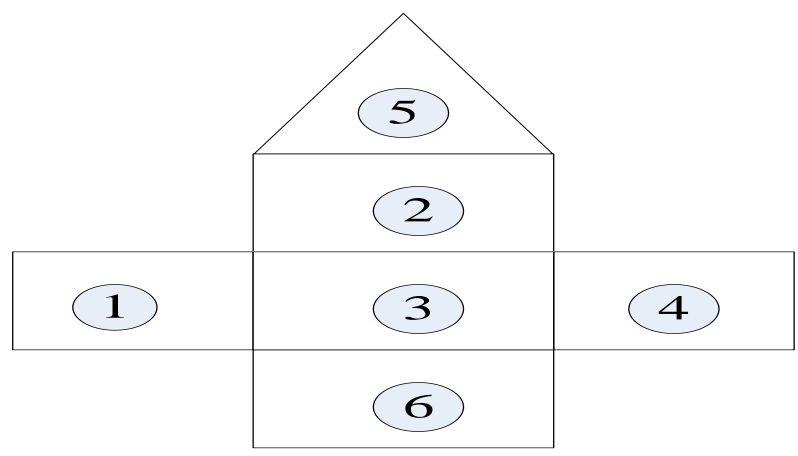

Figure 1. House of quality.

Research on QFD applied into educational fields begins from the late eighties abroad. In 1991,Ermer applied QFD to carry on the research which meets the customers(institute staffs, students, employing units)in the mechanical engineering college of Wisconsin-Madison University's for the first time[3].Afterwards, different scholars made some applied research concerning the improved teaching quality and teaching materials[4][5]. Bier etc. applied the QFD technology into AOM's master's degree outline building to meet the customers' demands and approval request by "acupuncture and oriental medical science approval committee" [6].

\section{Constructing of "House of Quality" for Advanced Vocational Education Curriculum Design}

\section{A. Acquisition of Customers' Needs}

Higher vocational education is to train advanced application-oriented talents for the forefront product-line. Competency-based is the essential features of higher vocational education, which to gain a clear idea of capacity and the corresponding knowledge, skill and attitude the practitioner of the professional fields post should be equipped by professional post survey and professional goal analysis; to design the curriculum, which needs to 
meet students' professional quality and professional skill needs, under the peculiar rules and the relevance and integration of various kinds of knowledge, skills and attitude by teaching analysis.

The basis of implementation and application of QFD successfully is whether can we acquire customer needs promptly and the needs are comprehensive, detailed and true or not. The QFD team should select the investigated orients scientifically. For the teaching service should meet different groups, it is difficult for QFD to discern the customers while applied into the higher vocational education management: students and their parents, the staffs, employing unit, government and society. As is shown in the Fig.2 [7], the founder of QFD Yoji Akao proposes two kinds of views concerning customers: internal customers and external customers. According to the classifications, QFD team ascertains the inner customer orients and the outer customer orients respectively, outer customers include potential employers, profession experts, and graduates while inner customers include students, teacher representatives and educational experts. Among which, students are not only the inner customers, but also the "products" in the educational procedure. As is shown in table 1, the QFD team adopts way of questionnaire to gain different needs of customers, then uses Affinity Diagram (KJ) to reorganize and analyze the requirements information, and get the customer needs expanding table which is professional technology talents abilities required standards by different patterns of customers. Since different customers' views of important rating towards different requirements are not identical, we adopt the level analysis methods (AHP) [8] to gain the importance of requirement. The QFD team designs the AHP questionnaire, in which every kind of customers select five representatives and make paired comparisons, then give them scores and mark of value uses $1,3,5,7,9$ to express the former to the latter respectively: equally important, moderately important,

TABLE I. DEPLOYMENT OF CUSTOMERS’ NEEDS AND SORT OF NEEDS’ IMPORTANCE

\begin{tabular}{|c|c|c|c|c|}
\hline \multicolumn{2}{|c|}{ Customer Needs } & $\begin{array}{l}\text { External } \\
\text { Customers }\end{array}$ & $\begin{array}{c}\text { Internal } \\
\text { Customers }\end{array}$ & $\begin{array}{c}\text { Overall } \\
\text { Ranking of }\end{array}$ \\
\hline \multirow{3}{*}{ Basic Quality } & $\begin{array}{l}\text { Basic cultural } \\
\text { knowledge }\end{array}$ & 9 & 6 & 8 \\
\hline & $\begin{array}{c}\text { Communication } \\
\text { skills, adaptability, } \\
\text { teamwork }\end{array}$ & 7 & 8 & 7 \\
\hline & $\begin{array}{c}\text { Responsibility, } \\
\text { professional ethics }\end{array}$ & 3 & 4 & 4 \\
\hline \multirow[b]{3}{*}{$\begin{array}{l}\text { Professional } \\
\text { Ability }\end{array}$} & Learning ability & 4 & 2 & 2 \\
\hline & $\begin{array}{c}\text { Innovative, } \\
\text { enthusiastic, } \\
\text { dynamic, challenging }\end{array}$ & 8 & 9 & 9 \\
\hline & $\begin{array}{l}\text { Ability to analyze } \\
\text { problems and the } \\
\text { ability to think, } \\
\text { technology } \\
\text { awareness }\end{array}$ & 5 & 7 & 6 \\
\hline \multirow{3}{*}{ Professional Skill } & $\begin{array}{c}\text { Professional } \\
\text { knowledge }\end{array}$ & 6 & 1 & 5 \\
\hline & $\begin{array}{l}\text { Professional and } \\
\text { technical capacity, } \\
\text { practical ability }\end{array}$ & 1 & 3 & 1 \\
\hline & $\begin{array}{l}\text { Familiar with the } \\
\text { technical methods } \\
\text { and tool }\end{array}$ & 2 & 5 & 3 \\
\hline
\end{tabular}


important, extremely important, absolutely important, and use geometric mean method to calculate the relative importance values of all kinds of requirements and order them. Eventually, we give two kinds of importance values different coefficients, then calculate overall importance values and make a sorting. The results are shown in table 1 .

\section{B. Features of Curriculum Design}

To a certain degree, advanced vocational education is an employment-oriented technical education. The substance of the curriculum design is to help students acquire or improve a career required technical knowledge, skills and qualities, and various professional fields have different characteristics so that the requirement of application talents is different. Therefore, the course design should be competence-based rather than subjectoriented. On the need of society and industry (business) for the basic skills of the front line personnel and studying in depth the main teaching content of various professional, advanced vocational education must avoid designing courses in the model of subject system, and to select the course content and to set legitimately the type and structure of the curriculum according to the corresponding characteristics of occupational groups or occupational. From the perspective of curriculum content, the setting of vocational course must meet objective knowledge, capabilities goals and quality targets. From the perspective of the functional curriculum, the curriculum objectives of vocational education can be divided into career preparation, career transition, career development, academic connection, and other properties. Specific to a particular profession, curriculum objectives have to consider different specifications of technology requirements of the training objectives. Therefore, the diversity features of vocational course objectives should be noticed when designing vocational courses, and to plan out rational curriculum system that communicate with each other and with their own characteristics.

On the basis of curriculum design in vocational education abroad, we propose the course structure featured of "Wide-based, Flexible Pattern" by combining with the special nature of vocational education in China. Widebased curriculum module represents the basic knowledge courses of culture and science whose goal is to develop students' cognitive and emotional ability. The essence of the so-called Flexible Pattern is a group curriculum system of knowledge and ability that is lower than subject curriculum and higher than subject curriculum which is similar with areas of expertise, it can be formed by a number of curriculum subjects. Flexible Pattern avoids the systematic and independence of original subject knowledge, and to cultivate professional competence of students aiming at the need of social and occupational. Flexible pattern includes vocational general course module and professional courses module. The vocational general course module is designed for a variety of career directions for a specific occupational group by taking out the common occupational group necessary knowledge and skills. It designs the general learning course combinations for a common occupational group and develops students of vocational technical tools, methods, and basic professional ability. Curriculum module, which is based on the different requirements of various professions, designs learning course combinations for various specialties and develops students' job skills and practical ability. After students completed the basic course modules and general course modules, they can select a professional to complete their academic course modules according to their preferences. The core curriculum of vocational general course is relatively stable, and professional courses are flexible and can respond to market competition and business needs. Since the Intrinsic science of the core curriculum and professional courses of a variety of selective, the course structure with sufficient flexibility, which greatly enhance students' employment flexibility.

\section{Building of "House of quality"}

Based on these studies, the customer needs and characteristics of curriculum design constitute twodimensional matrix or "house of quality" shown in Table 2. The row and column of matrix represents the needs of customers and the curriculum design features respectively. Transforming the customer needs namely the community standards of professional and technical personnel into the quality characteristics (course modules), QFD team study the correlation between each customer needs and curriculum design features carefully. A set of symbols used to represent the degree of correlation, the symbol $\bigcirc, \circ, \Delta$, respectively represent strongly 
correlation, medium correlation and weak correlation, and given the appropriate score 9-5-1, the importance of the conversion at the same time that the importance of quality requirements into the importance of quality characteristics Importance of the quality characteristic value is the importance of every customer need and the value of the correlation coefficient, the results shown in Table 2, last line. The results showed that basic knowledge of curriculum modules is secondary and the principle of curriculum design is enough and moderation in the vocational education. The common course modules and the professional courses module is a major, meanwhile, the curriculum enhance vocational skills training and practical skills training courses.

\section{Conclusions}

QFD is an effective method to transform customer requirements into product features. According to the special law of higher vocational education, on the basis of the requirement for the ability of vocational professional talent, the paper proposes a new QFD-based design of higher vocational education course to meet the needs of advanced vocational education. Results show that the method can reflect the "competence-based" essential characteristics of vocational education better and have a practical guiding significance for the vocational education curriculum design in our country.

\section{References}

[1] Bagchi, Uttarayan, "Delivering student satisfaction in higher education: A QFD approach" ,International Conference on Service Systems and Service Management, Proceedings of ICSSSM' 10, pp. 10491052,June 2010.

[2] J. Clerk Maxwell, A Treatise on Electricity and Magnetism, 3rd ed., vol. 2. Oxford: Clarendon, 1892, pp.68-73.

[3] I. S. Jacobs and C. P. Bean, "Fine particles, thin films and exchange anisotropy," in Magnetism, vol. III, G. T. Rado and H. Suhl, Eds. New York: Academic, 1963, pp. 271-350.

[4] Wang Keqin, Zhong Pei, Li Juan, "Application of QFD in enterprise requirements-oriented quality management of higher education", Proceedings - International Conference on Management and Service Science, MASS 2009.

[5] Sinthavalai Runchana, Memongkol Napisporn, "A case of FMEA implementation in the educational sector and integration with CRM and QFD concepts”, 2008 IEEE International Engineering Management Conference, Europe: Managing Engineering, Technology and Innovation for Growth.

[6] Y. Yorozu, M. Hirano, K. Oka, and Y. Tagawa, "Electron spectroscopy studies on magneto-optical media and plastic substrate interface," IEEE Transl. J. Magn. Japan, vol. 2, pp. 740-741, August 1987 [Digests 9th Annual Conf. Magnetics Japan, p. 301, 1982].

[7] M. Young, The Technical Writer's Handbook. Mill Valley, CA: University Science, 1989.

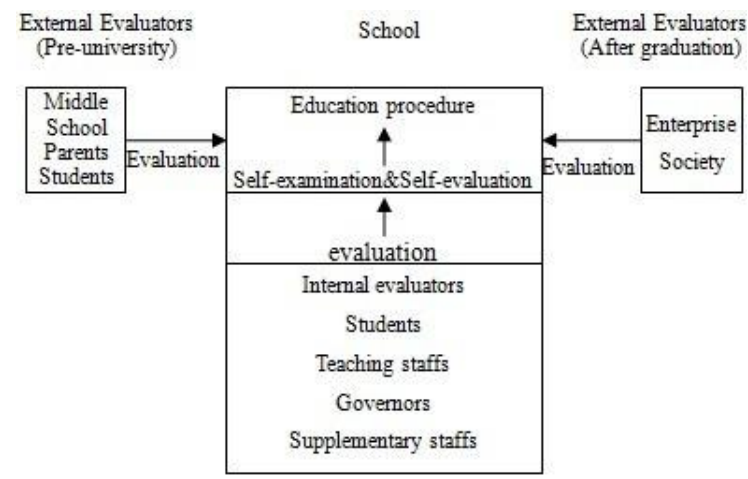

Figure 2. Akao's university education evaluation concept. 
TABLE II. "HOUSE OF QUALITY" OF CURRICULUM DESIGN

\begin{tabular}{|c|c|c|c|c|c|c|}
\hline \multicolumn{2}{|c|}{ Course features } & \multirow{2}{*}{$\begin{array}{c}\text { Basis } \\
\text { course } \\
\text { modul } \\
\text { es }\end{array}$} & \multirow{2}{*}{$\begin{array}{c}\begin{array}{c}\text { Vocatio } \\
\text { nal } \\
\text { general } \\
\text { basis } \\
\text { course } \\
\text { modules }\end{array} \\
\Delta \\
\end{array}$} & \multirow{2}{*}{$\begin{array}{c}\begin{array}{c}\text { Professio } \\
\text { nal } \\
\text { course } \\
\text { modules }\end{array} \\
\Delta\end{array}$} & \multirow{2}{*}{$\begin{array}{l}\begin{array}{c}\text { Importa } \\
\text { nce } \\
\text { weight of } \\
\text { customer } \\
\text { demand }\end{array} \\
5.1 \\
\end{array}$} & \multirow{2}{*}{\begin{tabular}{|l}
$\begin{array}{c}\text { Importance } \\
\text { order of } \\
\text { customer } \\
\text { demand }\end{array}$ \\
8
\end{tabular}} \\
\hline \multirow{3}{*}{$\begin{array}{l}\text { Basic } \\
\text { quality }\end{array}$} & $\begin{array}{l}\text { Basic cultural } \\
\text { knowledge }\end{array}$ & & & & & \\
\hline & $\begin{array}{l}\text { Communication } \\
\text { skills ,adaptability, } \\
\text { teamwork }\end{array}$ & $\circ$ & ○ & (0) & 5.4 & 7 \\
\hline & $\begin{array}{c}\text { Responsibility, } \\
\text { professional ethics }\end{array}$ & () & ○ & $\Delta$ & 7.2 & 4 \\
\hline \multirow{3}{*}{$\begin{array}{l}\text { Professiona } \\
\text { l ability }\end{array}$} & Learning ability & (0) & (0) & $\Delta$ & 8.9 & 2 \\
\hline & $\begin{array}{l}\text { Innovative, enthusiastic, } \\
\text { dynamic, challenging }\end{array}$ & 0 & (a) & $\circ$ & 4.7 & 9 \\
\hline & $\begin{array}{l}\text { Ability to analyze } \\
\text { problems and the ability } \\
\text { to think, technology } \\
\text { awareness }\end{array}$ & $\circ$ & () & $\circ$ & 6.1 & 6 \\
\hline \multirow{3}{*}{$\begin{array}{l}\text { Professiona } \\
\text { 1 skill }\end{array}$} & Professional knowledge & ० & o & (0) & 6.2 & 5 \\
\hline & $\begin{array}{l}\text { Professional and } \\
\text { technical capacity, } \\
\text { practical ability }\end{array}$ & $\Delta$ & $\Delta$ & () & 9.4 & 1 \\
\hline & $\begin{array}{l}\text { Familiar with the } \\
\text { technical methods and } \\
\text { tool }\end{array}$ & $\Delta$ & () & (0) & 7.3 & 3 \\
\hline $\begin{array}{l}\text { Courses } \\
\text { feature } \\
\text { weight }\end{array}$ & & 319.5 & 351.5 & 338.3 & & \\
\hline $\begin{array}{l}\text { Weight } \\
\text { order }\end{array}$ & & 3 & 1 & 2 & & \\
\hline
\end{tabular}

